\title{
1. BACKGROUND, OBJECTIVES, AND SUMMARY OF PRINCIPAL RESULTS: DEEP SEA DRILLING PROJECT SITES 556-5641
}

\author{
H. Bougault, Institut Français pour la Recherche et l'Exploitation de la Mer \\ and \\ S. C. Cande, Lamont-Doherty Geological Observatory ${ }^{2}$
}

\section{BACKGROUND}

\section{MORB Tholetiites, Transitional, and Alkalic Basalts}

One of the most important geologic discoveries of the 1960 s was the remarkable uniformity of the basalts produced at mid-ocean ridges. These basalts have a markedly different tholeiitic composition compared to the alkalic basalts from ocean islands (Engel et al., 1965). The major element compositions of ocean-floor basalts and the compositions of the phenocrysts when present (plagioclase, olivine, and, more rarely, clinopyroxene) were considered so similar in all of the oceans that the acronym MORB (mid-ocean ridge basalt) was used to characterize basalts formed at seafloor spreading ridges.

Just as remarkable, considering the homogeneity of mid-ocean ridge basalts, is the presence of sections of ridges where basalts of significantly different characteristics are found. For example, along the Mid-Atlantic Ridge at $45^{\circ} \mathrm{N}$, alkalic basalts and basalts with "alkalic tendencies" are associated with more normal tholeiitic basalts (Aumento, 1968). Trace element and isotopic ratio studies conducted in the past 15 years have shown that basalts produced at the mid-ocean ridges have a much greater variation than researchers originally realized. MORB now appears to be simply one end member of a broad spectrum of basalts of which alkalic basalt is the other end member; basalts of intermediate composition are referred to as "transitional basalts."

The occurrence of alkalic and transitional basalts is not random. In the North Atlantic they are generally found along abnormally shallow sections of the midocean ridge. Transitional basalts are found north of $60^{\circ} \mathrm{N}$ along the Reykjanes Ridge (Schilling, 1973) and along the Mid-Atlantic Ridge where it crosses the Azores Platform (Schilling, 1975). The occurrence of alkalic basalts at $45^{\circ} \mathrm{N}$ is also associated with a shallower than normal section of the Mid-Atlantic Ridge (Le Douaran and Francheteau, 1981). In addition, as already mentioned, alkalic basalts are characteristic of both ocean islands and seamounts. Furthermore, there is a gradient in the characteristics of transitional basalts from transitional to

\footnotetext{
${ }^{1}$ Bougault, H., Cande, S. C., et al., Init. Repts. DSDP, 82: Washington (U.S. Govt. Bougault, H., Cande, S. C., et al., Init. Repts. DSDP, 82: Washington (U.S. Govt.
Printing Office).
2 Addresses: (Bougault) Institut Français pour la Recherche et l'Exploitation de la Mer 2 Addresses: (Bougault) Institut Français pour la Recherche et l'Exploitation de la Mer
(formerly, Centre National pour l'Expolitation des Océans), Centre de Brest, B. P. 337, 29273 Brest Cedex, France; (Cande) Lamont-Doherty Geological Observatory, Columbia University, Palisades. New York 10964
}

normal MORB away from the highest elevations of the Iceland and Azores platforms (Schilling, 1973; 1975).

\section{$\mathrm{Sr}, \mathrm{Pb}$, and Nd Isotopic Ratios, Rare Earth Elements, and Mantle Sources}

Studies of radiogenic isotopes $(\mathrm{Sr}, \mathrm{Nd}, \mathrm{Pb})$ in ocean basalts have helped to classify the different basalt types and to interpret possible petrogenetic relationships (Gast, 1960; Gast et al., 1964; Tatsumoto et al., 1965). Variations in isotopic ratios of $\mathrm{Sr}$ (Tatsumoto et al., 1965; Hart et al., 1973; O'Nions and Pankhurst, 1974), Pb (Gast et al., 1964; Sun, 1973; Sun et al., 1975; Sun and Jahn, 1975; Tatsumoto, 1978), and Nd (DePaolo and Wasserburg, 1976; O'Nions et al., 1977; Richard et al., 1977) among MORB, transitional basalts, and alkalic basalts cannot be fully explained in terms of crystal fractionation and/or melting processes responsible for the formation of basalt from a mantle source. The differences in the isotopic compositions of these basalts can only be explained in terms of their derivation from different mantle sources.

Another important distinction between normal MORB and transitional and alkalic basalts lies in the relative abundances of those trace elements that have low mineral-liquid partition coefficients (Schneitzler and Philpotts, 1970). The best studied of these so called "magmaphile" elements (to indicate their affinity for the liquid phase) are the rare earth elements (Gast, 1968; Frey et al., 1968; Frey et al., 1974; Schilling, 1973, 1975; Sun et al., 1979; Bougault et al., 1980). MORB are typically "depleted" in the light rare earth elements (LREE) (relative to heavy rare earth elements [HREE]), whereas alkalic basalts are strongly enriched and transitional basalts are either "flat" or slightly enriched.

This relative enrichment or depletion of light rare earth elements is represented in a diagram proposed by Masuda (1962) and Coryell et al. (1963). The ratio of the concentration of each rare earth element in a given sample to its concentration in chondritic meteorites (the normalized concentration) is plotted against its atomic number. Normalized concentrations of the lightest rare earths ( $\mathrm{La}, \mathrm{Ce})$ are higher than the normalized concentrations of the middle to heavy rare earths (from Sm to $\mathrm{Lu}$ ) in enriched samples and vice versa. Flat patterns occur when all normalized concentrations are approximately equal. Examples of enriched (alkalic basalt from Site 410 at $45^{\circ} \mathrm{N}$ ), flat (Site 332 at $36^{\circ} \mathrm{N}$ ), and depleted (Site 395 at $22^{\circ} \mathrm{N}$ ) patterns are given in Figure 1. 


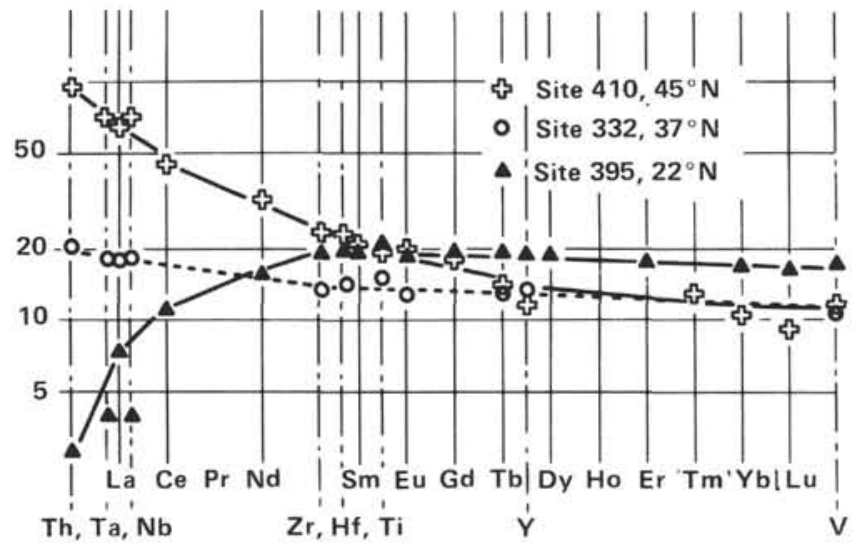

Figure 1. Coryell-Masuda diagram showing examples of Mid-Atlantic Ridge basalts that are enriched (Site 410), flat (Site 332), and depleted (Site 395). This is an "extended" Coryell-Masuda diagram because of inclusion of non-rare earth magmaphile elements, such as niobium and zirconium.

Theoretically, different relative light rare earth abundances in basalts may result from differences in mantle source composition, in extent of partial melting, or in the process by which melting occurs (Langmuir et al., 1977). However, variations in melting processes do not account for the known regional variation in patterns of enrichment or depletion of light rare earth elements in basalts. These regional patterns are assumed to reflect variations in the composition of mantle sources from which the basalts are derived. This inference is supported by correlations between the degree of light rare earth depletion or enrichment found in ocean basalts and variations in isotopic ratios of $\mathrm{Sr}, \mathrm{Pb}$, and $\mathrm{Nd}$ (White et al.,1976; White and Schilling, 1978; Dupré and Allègre, 1980; Zindler and Hart, 1978). Variations in relative abundances in the mantle of both isotopes and rare earth elements are attributed to fractionations of the primordial mantle early in the history of the Earth (O'Nions et al., 1978; Allègre et al., 1980).

The present-day geochemical properties of the upper mantle can be studied by dredging basalts from ridge crests. Upper mantle time variations can be studied by sampling older parts of the seafloor crust, which are found on the flanks of mid-ocean ridges. To obtain these older basalts, it is necessary to drill through the hundreds of meters of sediments that have been deposited since the basalts were formed at the ridge crest.

The topographic highs found along the axis of the midocean ridge, with which transitional basalts and sometimes alkalic basalts are associated, are not explained by general plate tectonic theory (Menard, 1967; Morgan, 1968; Sclater et al., 1971). Plate tectonics allows only for small variations in elevation near ridge crests (for example, variations in spreading rate) but cannot explain the exceptional topographic highs in the North Atlantic represented by the Iceland and Azores platforms. These topographic highs, or hot spots may be the surface manifestations of mantle plumes that bring magma up from mantle levels deeper than the levels that normally feed mid-ocean ridges (Morgan, 1971). These mantle plumes may also contribute to the driving forces that move the lithospheric plates. The mantle plume concept (or variations on it such as mantle blobs) can explain the apparently distinct mantle source of the "abnormal" ridge basalts associated with hot spots (Schilling, 1973; 1975). The gradients observed in basalt composition away from the centers of hot spots have also been explained by mixing of plume and nonplume sources (Vogt, 1972; Sun et al., 1975; White et al., 1976; O'Nions et al., 1976; White and Schilling, 1978).

Our knowledge of the distribution of transitional or alkalic basalts relative to normal MORB is limited to samples dredged at the ridge crest or recovered from the relatively few drill holes that have penetrated basement rocks. The most complete coverage is in the North Atlantic, particularly along the Mid-Atlantic Ridge in the vicinity of the Azores Triple Junction (Bougault and Hekinian, 1974; Bryan and Moore, 1977; White and Bryan, 1977; Hekinian et al., 1976), and the results of drilling at Sites 332, 333, 334, 335, 441, 412, and 413 (Aumento, Melson, et al., 1977; Luyendyk, Cann, et al., 1979). Chemical analyses of basalts dredged along the ridge crest show that there is a boundary at the latitude of the Hayes Fracture Zone $\left(33^{\circ} \mathrm{N}\right)$ between enriched basalts associated with the topographic high of the Azores and normal MORB associated with a deeper part of the Mid-Atlantic Ridge south of the Hayes Fracture Zone (White and Schilling, 1978; Bougault and Treuil, 1980).

Much less is known about the variations in time away from the ridge. The results of drilling along a flow line passing through the FAMOUS area (south of the Azores Triple Junction at $37^{\circ} \mathrm{N}$ ) on Legs 37 and 49 showed that transitional basalts with flat to enriched light rare earth elements are found in crust up to $10 \mathrm{Ma}$ old (Sites 332, $333,334,411,412$, and 413 ), but that basalts significantly depleted in light rare earth elements are found in crust 16.5 Ma old (Site 335) (Schilling et al., 1977). A transect along a flow line cutting across the Reykjanes Ridge south of Iceland recovered abnormal basalts at Sites 407 (35 Ma), 408 (20 Ma), and 409 (2.4 Ma). On the basis of magmaphile element abundances and $\mathrm{Sr}$ isotopic ratios, Site 409 is significantly different from Sites 407 and 408 (Wood et al., 1979a; 1979b). These results suggest that the composition of basalts formed at a particular section of a ridge crest within the zone influenced by topographic highs (hot spots) can change over a period of a few million years.

The results of drilling on a flow line south of the Kane Fracture Zone $\left(24^{\circ} \mathrm{N}\right.$ at its intersection with the rift axis), in an area where the ridge is much deeper and not influenced by abnormal topographic features, show that basalts were produced with uniform composition over a long period of time (Melson, Rabinowitz, et al., 1979; Donnelly, Francheteau, Bryan, Robinson, Flower, Salisbury, et al., 1980).

Samples recovered at the following places are all depleted: Anomaly Mo (110 Ma old; Sites 417, 418); Anomaly 5 (10 Ma old; Sites 395 [Melson, Rabinowitz, et al., 1979] and 396 [Dmitriev, Heirtzler, et al., 1979] almost symmetric with respect to the ridge); and samples recovered by dredging at the ridge crest. These results are consistent with a MORB mantle source that has re- 
mained uniform with time, but the gap of $100 \mathrm{Ma}$ between Anomalies 5 and Mo will have to be sampled for confirmation.

\section{OBJECTIVE}

\section{Trace Element Geochemistry}

As stated in the foregoing discussion, very little is known about temporal variations in the composition of basalts derived from one or several mantle sources associated with both normal and anomalously shallow sections of the mid-ocean ridges. A more detailed knowledge of these variations is required if we are to better understand the relationship between mantle sources and anomalous topographic features.

The principal objective of Leg 82 of the Glomar Challenger was to try to relate regional variations in basalt chemistry to the geodynamics of an abnormal section of the mid-ocean ridge. Specifically, we planned to relate the chemical characteristics of basalts sampled on the flanks of the Mid-Atlantic Ridge to the functioning of the Azores Triple Junction topographic high or "Azores hot spot." The Azores area was chosen for this study because it is perhaps the best studied abnormal region of mid-ocean ridge. Dredging along the ridge is extensive, and drilling on crust up to $16 \mathrm{Ma}$ old has already taken place on a flow line passing through the FAMOUS area $\left(37^{\circ} \mathrm{N}\right)$.

Because so little was known about how depleted and enriched rocks were distributed in this area, a grid of sites planned ahead of time might have fallen completely within the bounds of either enriched or depleted material and would have revealed very little about the regional distribution of the various types of basalts. Consequently, we wanted to determine the nature of the basalts as they were recovered and to use this information to determine where to drill next. The composition of the basalts was determined by X-ray fluorescence (XRF) in a van specially provided by The Centre National pour l'Exploitation des Océans $(\mathrm{CNEXO})^{3}$ and placed on board the Challenger. The CNEXO XRF van was first used in 1974 (Leg 37; Bougault, 1977) and has been used successfully on several subsequent occasions. Although in the past the van had been used chiefly to determine major element abundances, on Leg 82 the priority was to determine the abundances of magmaphile trace elements that could be used to distinguished enriched and depleted basalts.

Strictly speaking, the enrichment or depletion of the LREE determines whether a basalt is abnormal or normal. Unfortunately, the rare earth element abundances are too low to be determined by XRF analysis and can only be studied in shore-based laboratories. However, several trace elements qualitatively show the same tendency as rare earth elements to remain in the silicate liquid phase rather than to enter into the mineral phase. These magmaphile elements have already been studied in ocean basalts (Cann, 1970; Erlank and Kable, 1976)

\footnotetext{
${ }^{3}$ Funded by CNEXO, Délegation Générale à la Recherche Scientifique et Technique, and Centre National de la Recherche Scientifique.
}

and have been used for discriminant analysis (Pearce and Cann, 1971) and for tentative quantitative assessment of magmatic processes (Treuil and Varet, 1973; Treuil and Joron, 1975). For alkalic and tholeiitic basalts, some elements have chemical properties very similar to those of particular rare earths (e.g., yttrium versus HREEs) or have been shown to behave like rare earth elements (zirconium, hafnium, and titanium versus samarium; tantalum and niobium versus lanthanum) (Bougault et al., 1979). These elements can be used to deduce the shape of the Coryell-Masuda diagram, which represents the rare earth concentrations of a sample normalized to chondrites (Bougault, 1980; Bougault and Treuil, 1980). Figure 1 shows that the Coryell-Masuda diagram can be extended to other magmaphile elements. Thus, non-rare earth magmaphile elements define the same enriched or depleted patterns as the rare earths.

The abundances of the trace elements $\mathrm{Nb}, \mathrm{Z}, \mathrm{Ti}, \mathrm{Y}$, and $\mathrm{V}$ were determined by the XRF unit on board the Glomar Challenger. The most important element to be studied was $\mathrm{Nb}$ because its behavior closely mimics the lightest of the rare earth elements (e.g., La) and therefore fluctuates the most. The $\mathrm{Nb} / \mathrm{Zr}$ ratio is a key indicator of enrichment or depletion, almost identical to the $\mathrm{La} / \mathrm{Sm}$ ratio. The determination $\mathrm{Nb}$ concentration had not been done on board before and required an accuracy better than $1 \mathrm{ppm}$ in the range of concentrations from 0 to $15 \mathrm{ppm}$ (for a detailed discussion of this analysis, see Etoubleau et al., this volume).

The strategy for drilling on this cruise was to set up a broad grid encompassing all possible drilling sites west and southwest of the present Azores Triple Junction. On each flow line drilling started at an intermediate distance from the ridge and, depending on the XRF results, subsequent sites were drilled either closer to the ridge or further away. In this way, the boundary between normal and abnormal basalts along several flow lines could be quickly established.

The proposed drill sites for Leg 82 are shown in Figure 2. The sites situated along flow lines passing (1) through the Azores Triple Junction (MAR-1 to MAR-3), (2) through the FAMOUS area and the sites drilled on Leg 37 (MAR-4 and MAR-5), and (3) straddling the Hayes Fracture Zone (MAR-6 to MAR-11). The sites are located on magnetic Anomalies 6, 13, and 24 for the two northern transects and on magnetic Anomalies 5, 6, and 13 straddling the Hayes Fracture Zone. This network of sites provided information along both flow lines and isochrons over a wide area and provided valuable information, not only for the specific objectives of the cruise, but for other studies of the ocean crust.

\section{Geophysical Logging and Sediment Studies}

The principal objective of Leg 82 was to study mantle heterogeneity by sampling the ocean crust in the manner described above. Three other objectives were planned to take advantage of the opportunity to log basement holes and to collect pelagic sediments in the North Atlantic.

DSDP has accumulated a large and valuable data bank of physical property measurements on recovered cores. Borehole logging is a very desirable complement 
to these data; it can provide a continuous record of in situ physical properties, largely avoiding the deformation and systematic sampling bias inherent in core recovery. It was hoped that it would be possible to log several deep penetration holes to allow comparison of logs with physical property measurements on cores.

Within sediments, which may be expected in this area to be fairly uniform pelagic ooze, it would be interesting to compare physical properties measured on the cores to in situ values. Additionally, it may be possible to correlate between holes with sufficient downhole logs. Within the basalt basement, physical properties of core specimens changed little during the coring operation; however, core recovery averaged only $50 \%$ at best, so it is possible that a truly representative sample was not recovered.

Comparison between downhole logs and cored material can: (1) locate the accurate depth of lithologic unit boundaries, which are always indeterminate to some extent unless core recovery is $100 \%$; (2) provide evidence of the degree to which the recovered core represents the total section and can locate and identify nonrecovered lithologic units; (3) facilitate quantitative estimation of in situ physical properties, such as secondary porosity, bulk-formation density, and seismic velocity.

It was hoped that logging of deep holes in mediumage ocean crust (15-30 Ma) could provide information about the aging processes of ocean crust when combined with results from previous legs (particularly 37,51 , and 52). Particular features that may be available from log data would be the changes in primary and secondary porosity. This would reflect mineral alteration, faulting, and fracture infilling processes.

Until now, complete section of Cenozoic pelagic sediments has been cored in the North Atlantic. Investigation of the sedimentation, stratigraphy, paleoenvironments, paleomagnetics, and geologic history of this area has been limited to spot cores and partial sections. At Site 334 (Leg 37) a thick section of upper Miocene calcareous pelagic ooze and chalk was cored. At Site 335, five spot cores were taken though $450 \mathrm{~m}$ of Pleistocene through middle Miocene sediments. A small number of spot cores were taken in Pleistocene to Eocene sections at Sites 10 and 11 (Leg 2). Other sites in the North Atlantic region recovered Cenozoic sections consisting principally of turbidites and hemipelagic sediments.

In order to fill a large gap in sampling and to provide data for study of the Cenozoic history, paleomagnetics, and paleoenvironment of the North Atlantic, continuous coring should be done at as many sites as possible within the constraints of time imposed by the principal objective of the leg. The sites chosen for continuous coring should be determined by several criteria including (1) age of the section to be recovered and (2) probability of recovering a complete section above the calcite compensation depth (CCD) for biostratigraphic zonation and magnetostratigraphic dating. A well-chosen site on Anomaly 13 should provide a complete section through the Neogene and most of the Oligocene. A site on Anomaly
24 would also penetrate most of the Eocene. Continuous coring at such sites would satisfy the sediment objectives of the leg by providing samples for biostratigraphic, paleoclimatic, paleoenvironmental, sedimentologic, and paleomagnetic studies in this area. Hydraulic piston coring should be a high priority of this sediment program.

Recent paleomagnetic studies on terrestrial and marine sediments have shown that magnetostratigraphy is very important and useful for absolute chronostratigraphic correlation. The use of the hydraulic piston corer (HPC) is important to get the least disturbed sediments essential for successful paleomagnetic studies. The increasing hardness of the sediments with depth limited the use of the HPC and required coring to be done by conventional rotary coring. The detailed magnetostratigraphic work done on sediments cored by the HPC and the conventional methods during Legs 68 and 73 has further emphasized the need to do more work in order to establish the absolute temporal correlation of sediments, which, in turn, is of great significance for paleoenvironmental studies and tectonic analysis of the various ocean basins.

\section{PRINCIPAL RESULTS}

As the cruise progressed, each site was selected from a grid of 11 potential locations (Fig. 2) on the basis of shipboard chemical determinations of abundances of key trace elements: niobium, zirconium, titanium, yttrium, and vanadium (Etoubleau et al., this volume). Specifically, the chondrite-normalized $(\mathrm{Nb} / \mathrm{Zr})_{\text {ch }}$ ratio, was used to determine the enriched or depleted character of recovered basalts. On this basis, the first drilled site (556) at the location of MAR-2 on the Azores Triple Junction flow line (Figs. 2, 3) was found to be typical of depleted ocean crust without significant influence of the Azores Hot Spot plume, with $(\mathrm{Nb} / \mathrm{Zr})_{\text {ch }}$ ratio ranging from 0.15 to 0.30 (Table 1). Considering this result, we drilled the next site (557) closer to the Azores Triple Junction at the location of MAR-1 (Figs. 2, 3). Site 557 is typical of the Azores area, with enrichment factors lying between 1.3 and 1.9 for $(\mathrm{Nb} / \mathrm{Zr})_{\text {ch }}$ ratio (Table 1$)$.

During Leg 82 , there was not enough time to drill all potential locations (Fig. 2), so we decided to drill other holes close to Anomalies 6 and 13 in order to obtain a coherent picture along two isochrons. The drilled sites during Leg 82 are presented in Figure 3. The stratigraphy of Leg 82 sites is shown in Figure 4.

On board, 163 samples were selected and analyzed for both major elements (except $\mathrm{Na}_{2} \mathrm{O}$ ) and trace elements. The data that were later obtained on shore (Bougault et al., Rideout and Schilling, Weaver et al., Brannon, Hertogen et al., Drake et al., this volume)-including classic rare earth element data-confirmed all of the shipboard data. In addition, isotopic data were obtained after the cruise (Rideout and Schilling, Jenner et al., Dupré et al., this volume) and are reported in the Geochemistry part of this volume. Figures 5 and $6(\epsilon \mathrm{Nd}$ versus $\mathrm{Nb} / \mathrm{Zr}$ and $\epsilon \mathrm{Nd}$ versus $\mathrm{La} / \mathrm{Ta}$ ) compare trace ele- 


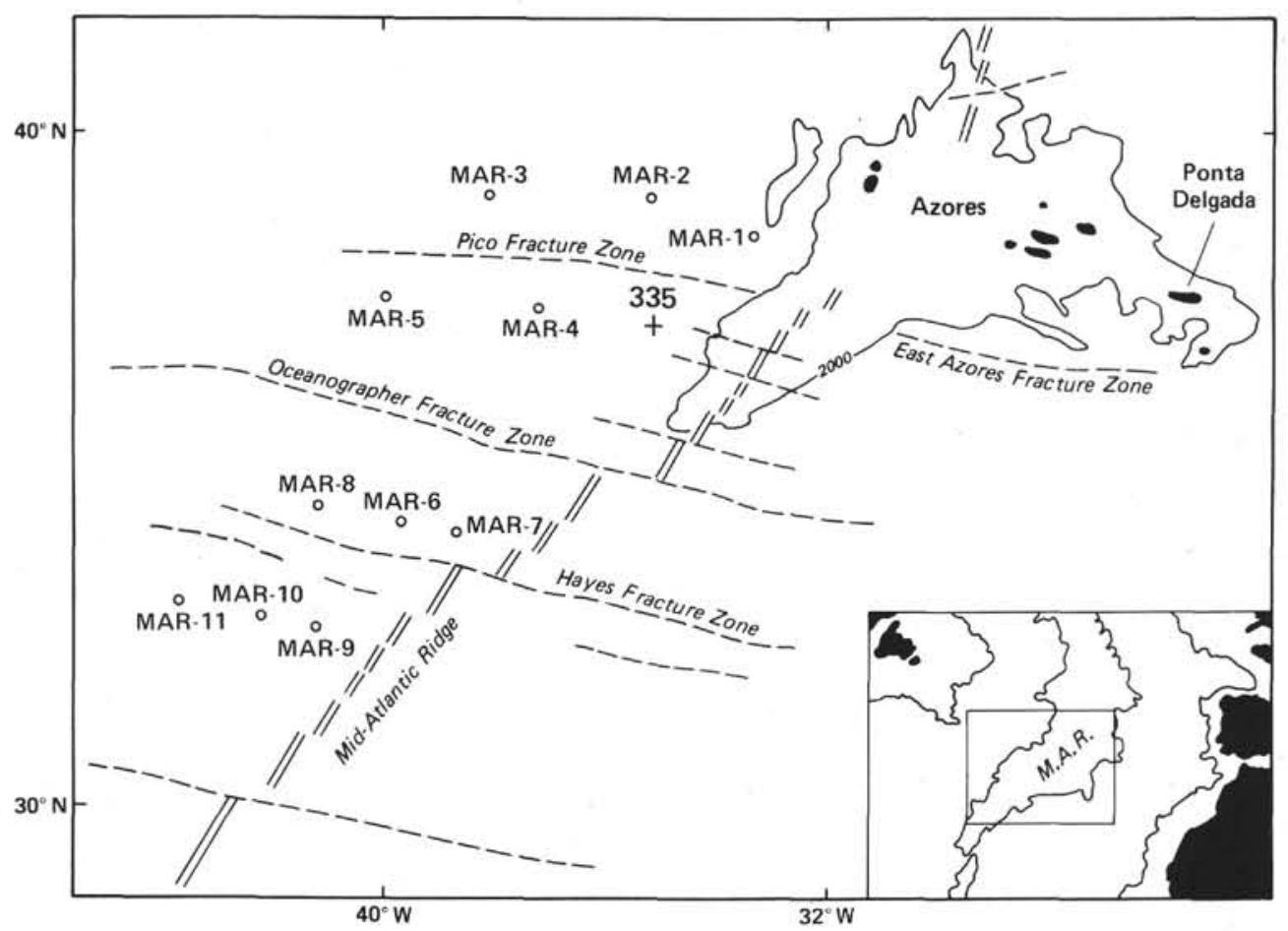

Figure 2. Proposed Leg 82 site locations.

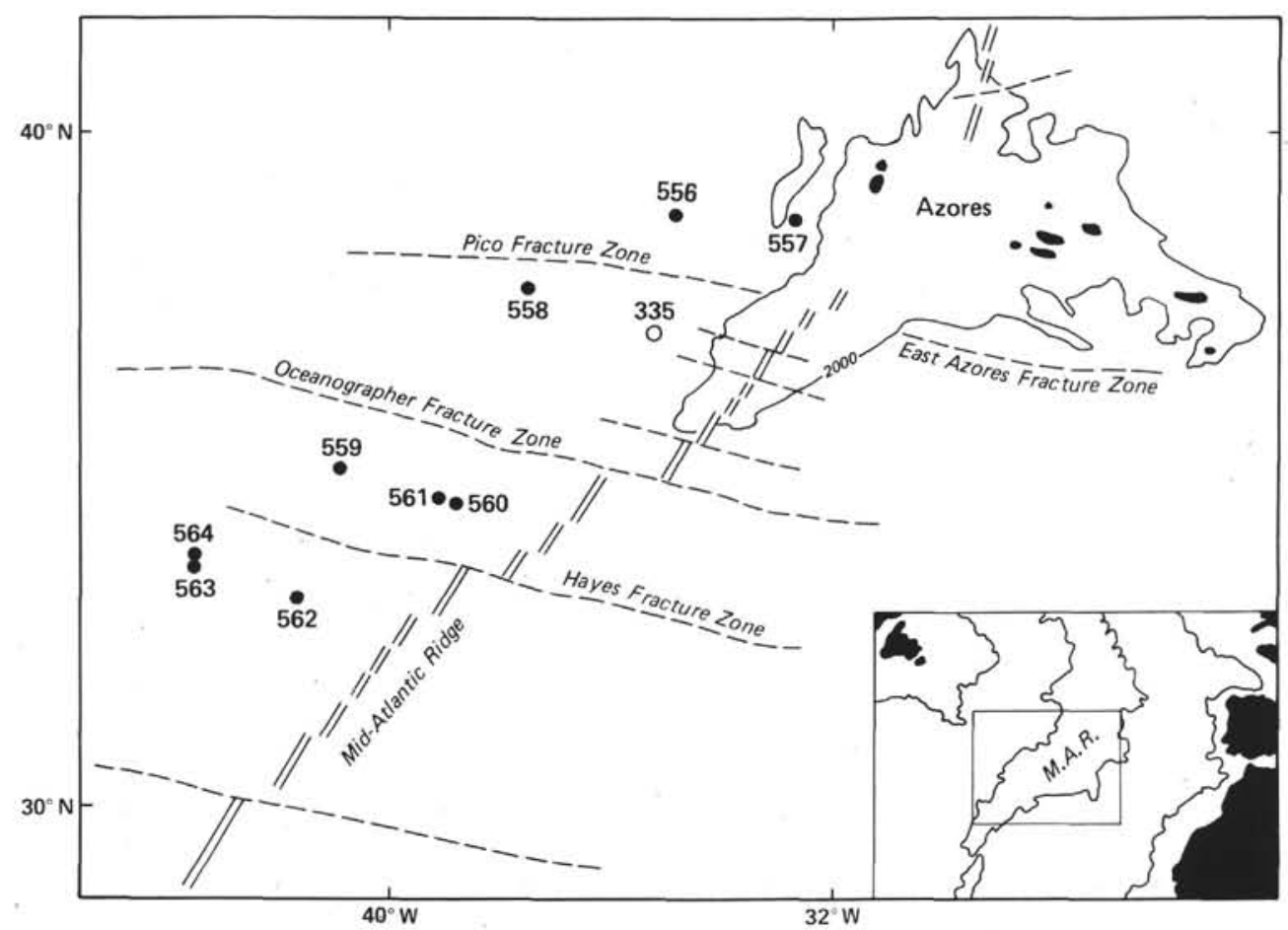

Figure 3. Leg 82 drill sites.

ment and isotope abundances; Figure 7 shows the comparison between two isotopic ratios $\left({ }^{206} \mathrm{~Pb} /{ }^{204} \mathrm{~Pb}\right.$ versus $\epsilon \mathrm{Nd})$.

\section{Site 556}

Hole 556 was drilled on Anomaly 12 on the west flank of the Mid-Atlantic Ridge, about 50 miles north of the
Pico Fracture Zone on a flow line passing through the Azores Triple Junction (Fig. 3). At $461 \mathrm{~m}$ sub-bottom, basalts occur as clasts in breccias, as pillow flows, and as massive flows. On the basis of macro- descriptions and microscopic descriptions of the samples, together with on-board chemical analyses, four chemically distinct basalt groups were defined within the different lith- 
Table 1 . Leg 82 coring summary.

\begin{tabular}{|c|c|c|c|c|c|c|c|c|c|c|c|}
\hline Hole & $\begin{array}{l}\text { Dates } \\
(1981)\end{array}$ & $\begin{array}{l}\text { Latitude } \\
\text { (all north) }\end{array}$ & $\begin{array}{l}\text { Longitude } \\
\text { (all west) }\end{array}$ & $\begin{array}{l}\text { Water } \\
\text { depth } \\
\text { (m) }\end{array}$ & $\begin{array}{l}\text { Penetration } \\
\text { (m) }\end{array}$ & $\begin{array}{c}\text { Sediment } \\
\text { thickness } \\
\text { (m) }\end{array}$ & $\begin{array}{l}\text { No. of } \\
\text { cores }\end{array}$ & $\begin{array}{c}\text { Total } \\
\text { meters } \\
\text { cored }\end{array}$ & $\begin{array}{c}\text { Basement } \\
\text { cored } \\
\text { (m) }\end{array}$ & $\begin{array}{c}\text { Basement } \\
\text { recovery } \\
(\%)\end{array}$ & $\begin{array}{c}(\mathrm{Nb} / \mathrm{Zr})_{\text {ch }} \\
\text { range }\end{array}$ \\
\hline 556 & 22-29 September & $38^{\circ} 56.38^{\prime}$ & $34^{\circ} 41.12^{\prime}$ & 3672 & 639.0 & 461.5 & 22 & 184.0 & 177.5 & 44.6 & $0.15-0.30$ \\
\hline 557 & 29-30 September & $38^{\circ} 49.95^{\prime}$ & $32^{\circ} 33.58^{\prime}$ & 2143 & 463.5 & 460.0 & 1 & 3.0 & 3.0 & 40.0 & $1.30-1.90$ \\
\hline 558 & 3-11 October & $37^{\circ} 46.24^{\prime}$ & $37^{\circ} 20.61^{\prime}$ & 3754 & 561.0 & 406.0 & 44 & 403.5 & 155.0 & 38.4 & $0.50-1.60$ \\
\hline $558 \mathrm{~A}$ & 11-12 October & $37^{\circ} 46.24^{\prime}$ & $37^{\circ} 20.61^{\prime}$ & 3754 & 131.5 & 406.0 & 16 & $131.5^{\mathrm{a}}$ & & & \\
\hline 559 & 14-16 October & $35^{\circ} 07.45^{\prime}$ & $40^{\circ} 55.00^{\prime}$ & 3754 & 301.0 & 238.0 & 8 & 63.0 & 63.0 & 37.0 & 1.5 \\
\hline 561 & 18-20 October & $34^{\circ} 47.10^{\prime}$ & $39^{\circ} 01.70^{\prime}$ & 3459 & 426.5 & 411.5 & 3 & 15.0 & 15.0 & 40.0 & $0.30-2.20$ \\
\hline 562 & 21 24 October & $33^{\circ} 08.49^{\prime}$ & $41^{\circ} 40.76^{\prime}$ & 3172 & 331.0 & 240.0 & 11 & 90.0 & 90.0 & 44.9 & 0.30 \\
\hline 563 & 24-28 October & $33^{\circ} 38.53^{\prime}$ & $43^{\circ} 46.04^{\prime}$ & 3786 & 382.5 & 364.0 & 25 & 226.0 & 18.5 & 48.7 & 0.30 \\
\hline 564 & 28 October-1 November & $33^{\circ} 44.36^{\prime}$ & $43^{\circ} 46.03^{\prime}$ & 3820 & 365.0 & 284.0 & 9 & 81.0 & 81.0 & 43.0 & $0.37-0.54$ \\
\hline
\end{tabular}

a Percent recovery piston coring: 94 .

b Only serpentinized gabbro and serpentine.

ologic units. Below $561 \mathrm{~m}$ sub-bottom, to the bottom of the hole $(78 \mathrm{~m})$ the core contained two units of partially to completely serpentinized gabbro breccia separated by a thin basalt layer. The depleted character $\left[(\mathrm{Nb} / \mathrm{Zr})_{\mathrm{ch}}=\right.$ 0.15 to 0.3 ] of all basalts recovered at Site 556 is well correlated with normal topography of the ocean floor at this site. Nevertheless, although Figures 5 and 6 confirm that the basalts at Site 556 are typical of "normal" ocean crust, with $\epsilon \mathrm{Nd}$ of about 10 , Figure 7 shows that the ${ }^{206} \mathrm{~Pb} /{ }^{204} \mathrm{~Pb}$ values are much closer to values expected for "enriched" material. This result limits the understanding of mantle heterogeneities because it cannot be explained simply by mixing of two well-defined end-member-type mantle sources (e.g., depleted low-velocity-zone [LVZ]-type and enriched plume type). The combination in the same sample of depletion in magmaphile elements, of high $\epsilon \mathrm{Nd}$ value, and also of high $\mathrm{Pb}$ isotopic ratios required that a particular mantle source was isolated a long time ago from either an Azores-plume-type or LVZ-type source.

The geothermal gradient is $36^{\circ} \mathrm{C} / \mathrm{km}$ within the sediment above basement. A complete set of logs were run upon completion of the hole. These logs showed a constant temperature of about $2^{\circ} \mathrm{C}$ down to the sediment/ basement interface, suggesting that seawater was flowing into the hole.

\section{Site 557}

Site 557 is located on Magnetic Anomaly 5D at the center of a broad elevated basin on the same flow line as Site 556 passing through the Azores Triple Junction (Fig. 3). After the discovery of depleted ocean crust at Site 556 (in contrast to the well-known enriched character of the ocean crust in the area of the triple junction), we deemed it important to verify the presence of enriched material closer to the ridge crest. In a duel with hurricane Irene, we had just enough time to core $3 \mathrm{~m}$ of basalt before being forced to abandon the hole. The high-Fe-Ti, coarse-grained aphyric basalts recovered there have the same typical enriched character $\left[(\mathrm{Nb} / \mathrm{Zr})_{\mathrm{ch}}=\right.$ 1.3 to 1.9 ] found at the spreading center in the area of the Azores Triple Junction. This result has been confirmed by isotope data.

\section{Site 558}

Site 558 is located between Anomalies 13 and 15 on a flow line passing through the FAMOUS area $\left(36^{\circ} \mathrm{N}\right)$ and through younger off-axis sites drilled during Legs 37 and 49 (Fig. 3). We decided on a complete program of coring (both sediment and basement) and logging to complement the large amount of data already available near and at the ridge crest.

The upper part of the basement of Site 558 consists of nine lithologic units of aphyric basalt-mostly pillow basalts with variable amounts of interpillow breccia and some basalt breccias (Fig. 4). Fresh glass is very common at pillow margins throughout the basalt layer. Calcite and/or limestone fills cracks and interpillow spaces. The deeper basement cores contain two lithologic units of serpentinized gabbro, fresh and altered serpentinite, serpentinite breccia, and mylonite.

On the basis of chemical analyses of 29 samples of the basalt layer, we identified six homogeneous chemical groups (Table 2 shows the average compositions). No cogenetic relationship exists between the different groups. The most striking result obtained at Site 558 is the occurrence, in the same hole, of depleted $\left[(\mathrm{Nb} / \mathrm{Zr})_{\mathrm{ch}}=\right.$ $0.4]$, flat $\left[(\mathrm{Nb} / \mathrm{Zr})_{\mathrm{ch}}=1\right]$, and enriched $\left[(\mathrm{Nb} / \mathrm{Zr})_{\mathrm{ch}}=\right.$ 1.6] patterns of magmaphile element abundance (Fig. 8). After Sites 413 (Leg 49) and 504 (Legs 69 and 70), Site 558 is the third site presenting this feature.

Glass and bulk-rock samples show rather evolved $\mathrm{Pb}$ isotopic composition (Fig. 7) and extend the domain of the Atlantic Ocean basalts in lead-lead diagrams (Dupré et al., this volume).

In addition to the range of variation in isotopic ratios (Fig. 7), enriched and depleted $(\mathrm{Nb} / \mathrm{Zr}$ or $\mathrm{La} / \mathrm{Ta}$ ratio) values occur that correspond to the same $\epsilon \mathrm{Nd}$ value (Fig. 5 and 6). Some basalts defined as "normal" midocean ridge basalts (MORB) by magmaphile-element characteristics have $\epsilon \mathrm{Nd}$ values typical of "enriched" MORB. This is a significant deviation to a general rule that would predict a perfect correlation between trace-element and isotopic ratios. Recent events can modify the trace-element characteristics from an "enriched" to a "depleted" signature without changing the "enriched" signature of isotopes (Langmuir et al., 1977; Bougault et al., 1979). 

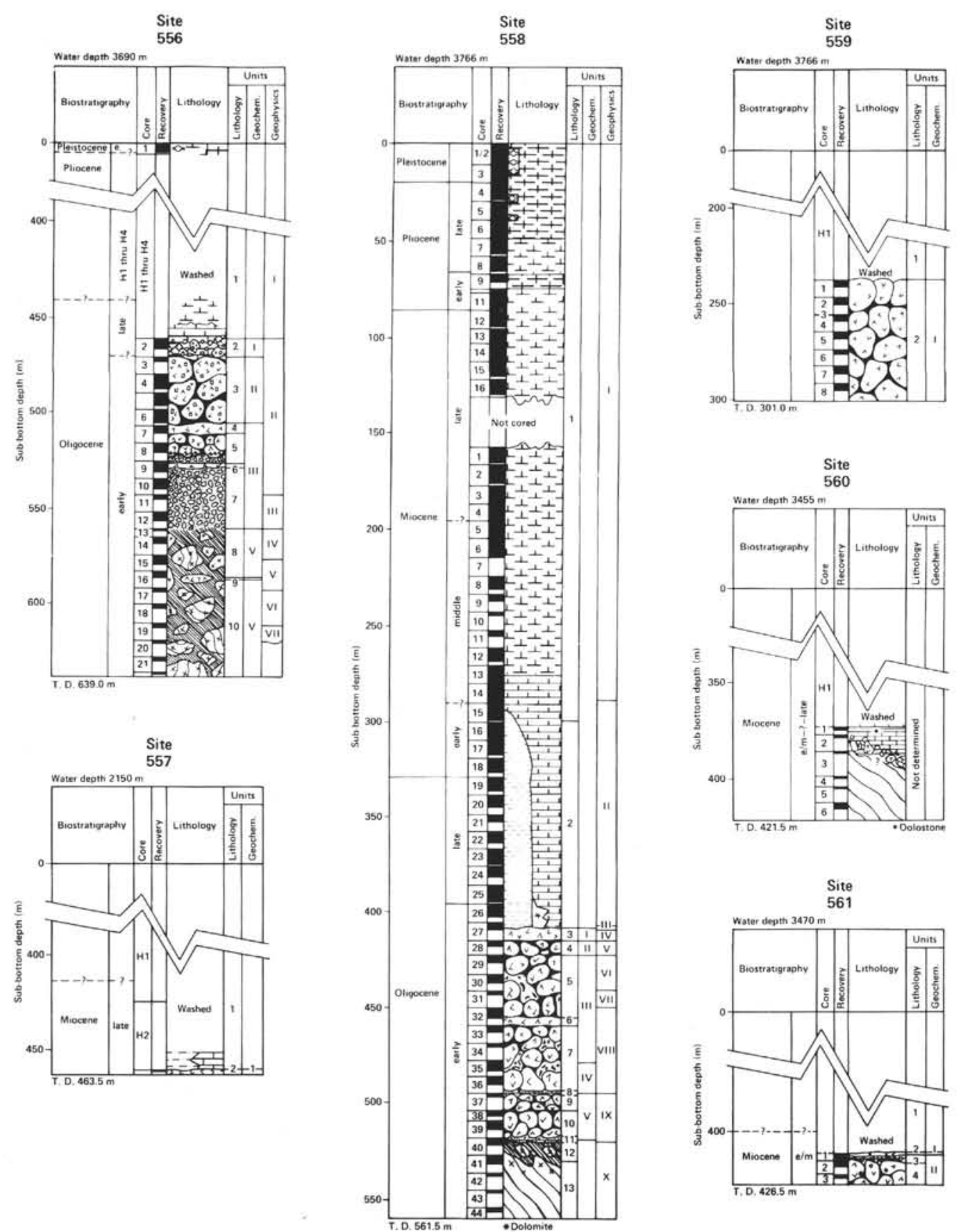
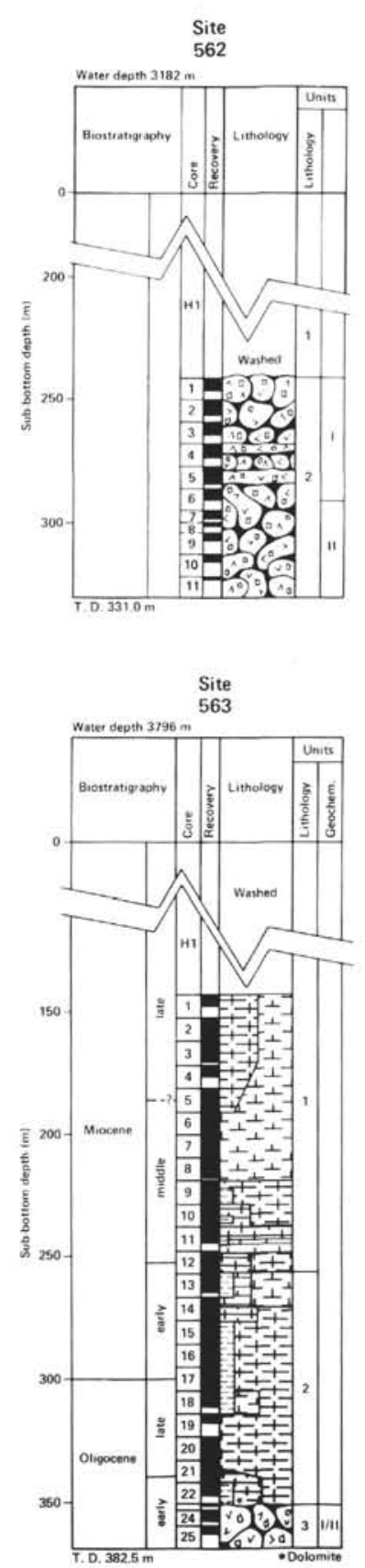

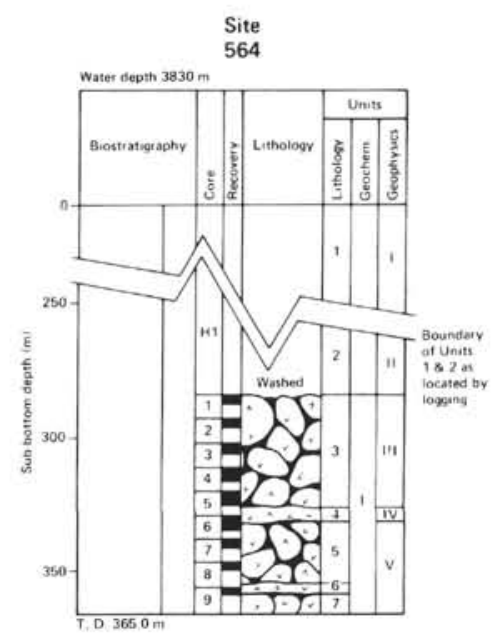

\begin{tabular}{|c|c|}
\hline 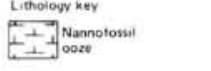 & 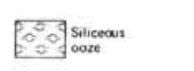 \\
\hline $\begin{array}{l}\text { Foram nanno } \\
\text { oure }\end{array}$ & $\Gamma_{M^{\text {Nanalk }}}^{\text {Nanotomil }}$ \\
\hline$\square$ & \begin{tabular}{lll} 
frasm Namno \\
\hdashline
\end{tabular} \\
\hline 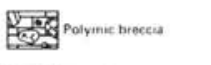 & 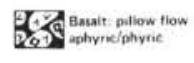 \\
\hline 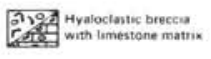 & 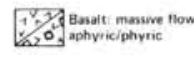 \\
\hline 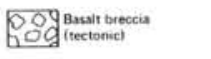 & $\because \because]_{\text {Gatboro }}$ \\
\hline 堅Limestone & $\Delta V_{\text {serpentsite }}$ \\
\hline$E=$ Multstone & 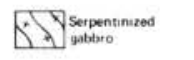 \\
\hline 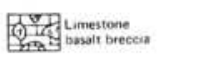 & E. Cataciantic \\
\hline
\end{tabular}




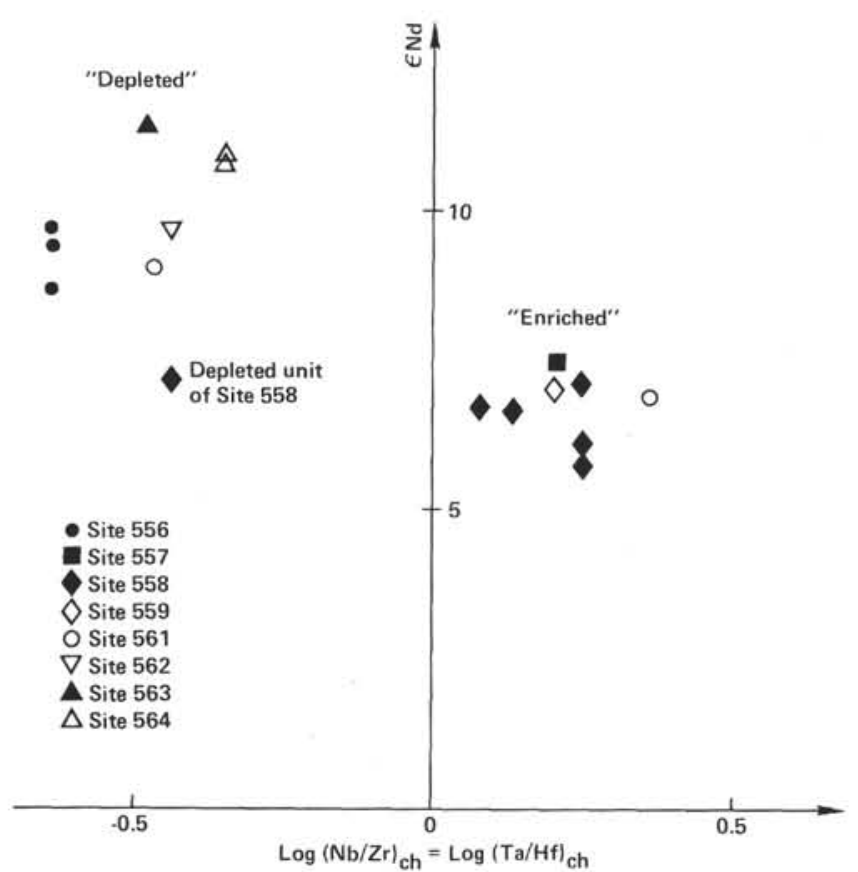

Figure 5. $\epsilon \mathrm{Nd}$ versus $\log (\mathrm{Nb} / \mathrm{Zr})$. The logarithm of the normalized ratio of $\mathrm{Nb} / \mathrm{Zr}$ on the $x$ axis yields directly the enrichment or depletion factor observed from extended Coryell-Masuda plots (by definition, 0 corresponds to the flat distribution). (The normalized $\mathrm{Nb} / \mathrm{Zr}$ ratio is equal to the normalized $\mathrm{Ta} / \mathrm{Hf}$ ratio.)

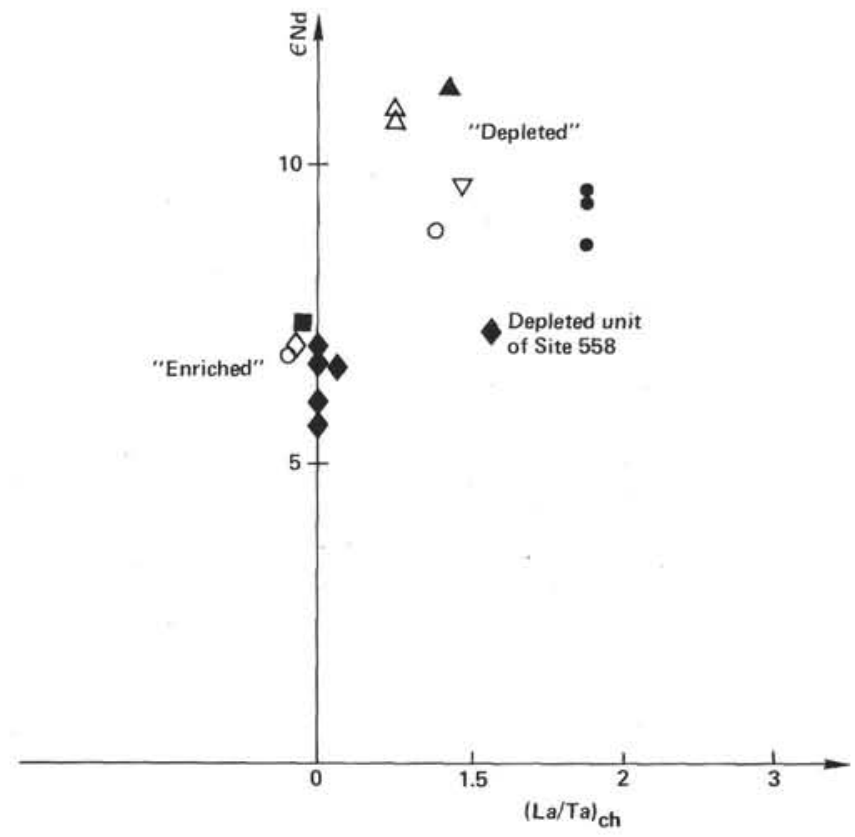

Figure 6. $\epsilon \mathrm{Nd}$ versus normalized $\mathrm{La} / \mathrm{Ta}$ ratio. This plot is chosen because of the well-known constant value of $\mathrm{La} / \mathrm{Ta}$ in basalts that exhibit flat-to-enriched patterns (mantle-plume type). Symbols as in Figure 5 .

Almost the entire sedimentary section $(406 \mathrm{~m})$ was recovered through a combination of piston coring (Hole $558 \mathrm{~A} ; 0-131.5 \mathrm{~m}$ ) and rotary coring (Hole $558 ; 158-406$ m) (Fig. 4). We have for the first time in the North Atlantic a continuously cored section of calcareous pelagic ooze and chalk that appears to be almost complete from

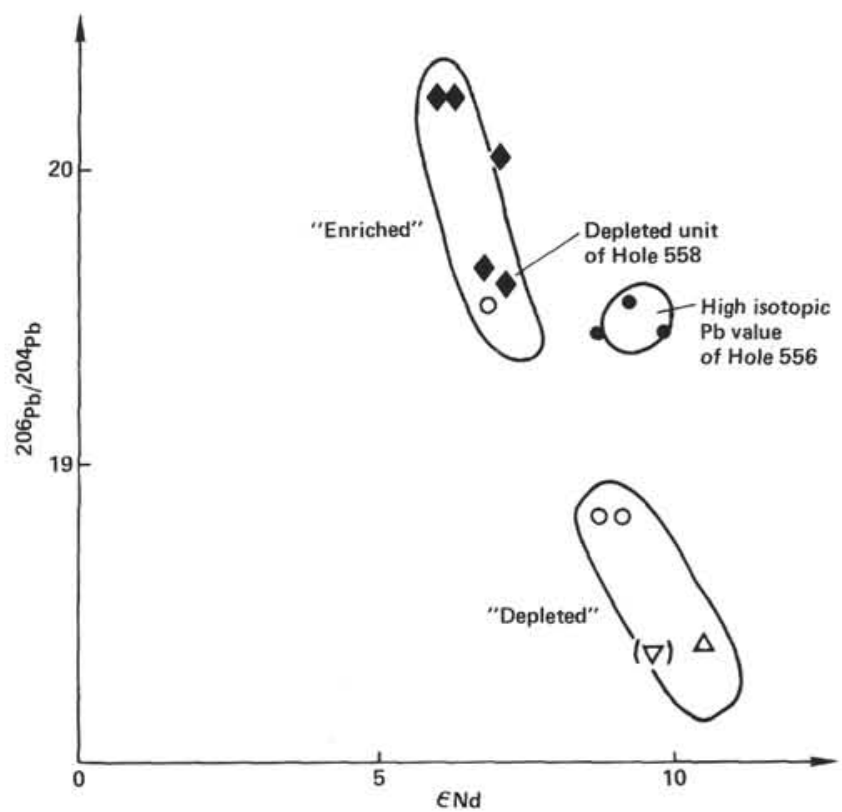

Figure 7. ${ }^{206} \mathrm{~Pb} /{ }^{204} \mathrm{~Pb}$ versus $\epsilon \mathrm{Nd}$. This plot shows possible anomalies in the correlation of isotopic ratios. Note the positions of samples from Hole 556, which are outside the two groups defined by Figures 5 and 6 . They have a very high $\mathrm{Pb}$ radiogenic ratio for an $\epsilon \mathrm{Nd}$ value of $\sim 9.5$. The parentheses around the Site 562 data point indicates that $\epsilon \mathrm{Nd}$ and ${ }^{206} \mathrm{~Pb} /{ }^{204} \mathrm{~Pb}$ were determined on different units (Dupré et al., Jenner et al., Rideout and Schilling, this volume). Symbols as in Figure 5.

Table 2. Averages of major-element and trace-element concentrations of the different units at Site 558: on-board determinations.

\begin{tabular}{ccccccc}
\hline Chemical group & I & II & III & IV & V & VI \\
\hline \multicolumn{1}{c}{$n$} & 1 & 3 & 13 & 5 & 6 & 1 \\
\hline $\mathrm{SiO}_{2}$ & 50.67 & 50.86 & 50.70 & 50.19 & 49.37 & 48.71 \\
$\mathrm{TiO}_{2}$ & 1.22 & 1.12 & 1.38 & 1.22 & 0.96 & 0.92 \\
$\mathrm{Al}_{2} \mathrm{O}_{3}$ & 14.10 & 15.11 & 14.82 & 14.65 & 15.49 & 15.81 \\
$\mathrm{Fe}_{2} \mathrm{O}_{3}$ & 10.92 & 10.08 & 10.17 & 10.98 & 10.17 & 10.73 \\
$\mathrm{MnO}$ & 0.16 & 0.15 & 0.15 & 0.16 & 0.16 & 0.16 \\
$\mathrm{MgO}$ & 9.87 & 7.69 & 8.33 & 8.90 & 9.48 & 10.55 \\
$\mathrm{CaO}$ & 10.55 & 12.23 & 11.64 & 11.90 & 12.06 & 11.56 \\
$\mathrm{~K}_{2} \mathrm{O}$ & 0.18 & 0.18 & 0.30 & 0.30 & 0.20 & 0.10 \\
$\mathrm{P}_{2} \mathrm{O}_{5}$ & 0.14 & 0.12 & 0.18 & 0.13 & 0.12 & 0.07 \\
$\mathrm{Ti}$ & 7320 & 6720 & 8280 & 7308 & 5780 & 5520 \\
$\mathrm{~V}$ & 207 & 255 & 275 & 266 & 224 & 194 \\
$\mathrm{Sr}$ & 128 & 92 & 175 & 144 & 115 & 107 \\
$\mathrm{Y}$ & 27.7 & 29.7 & 28.7 & 28.1 & 22.9 & 23 \\
$\mathrm{Zr}$ & 83 & 66 & 88 & 80 & 61 & 51 \\
$\mathrm{Nb}$ & 8.6 & 3.2 & 14.8 & 10.5 & 7.3 & 2 \\
$(\mathrm{Nb} / \mathrm{Zr})_{\text {ch }}$ & 1.00 & 0.47 & 1.63 & 1.27 & 1.16 & 0.38 \\
\hline & & & & & &
\end{tabular}

Note: $\mathrm{n}=$ number of samples on which mean is based.

the lower Oligocene through the lower Pleistocene. The age of the oldest sediment ( 34 to $37 \mathrm{Ma}$ ) obtained from nannofossils found in the basalt breccias at the top of basement is in agreement with the position of the hole between Magnetic Anomalies 13 and 15. A major change in the sediment lithology near the lower/middle Miocene boundary corresponds to a change in carbonate content ( $90 \%$ in the upper part, $50 \%$ below) and in the average sediment accumulation rate $(20 \mathrm{~m} / \mathrm{Ma}$ above and $8 \mathrm{~m} /$ Ma below).

Magnetostratigraphic studies of the lower part of the sedimentary section show a complete record of magnetic polarity reversals, correlating almost one to one with 


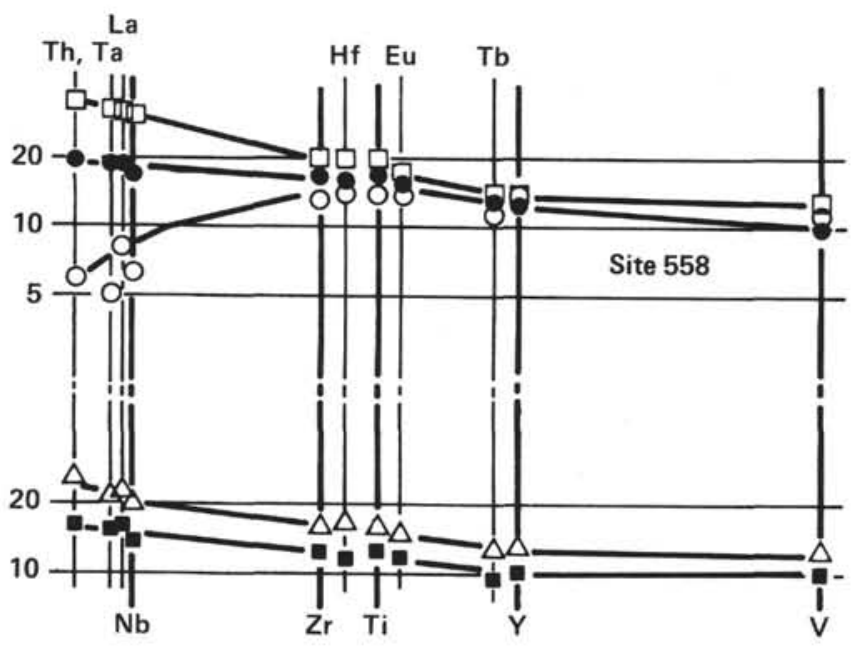

Figure 8. Hole 558: extended Coryell-Masuda plots. On the $x$ axis, the elements indicated at the bottom of the figure $(\mathrm{Nb}, \mathrm{Zr}, \mathrm{Ti}, \mathrm{Y}, \mathrm{V})$ were the objects of on-board measurements, whereas the concentrations of elements indicated at the top were determined on shore.

known reversals from Chron 16 to the lower part of Chron 12.

We attempted to run a complete set of geophysical logs, but owing to poor hole conditions, these were only partially successful. The major lithologic boundary in the sediments is clearly marked in the density, sonic, and resistivity logs and in shipboard physical properties measurements. We detected a similar change in the same logs at an equivalent depth at Site 556, implying that this lithologic change is probably a broad regional feature. Other minor changes within the sets of logs at Site 556 and 558 also appear to coincide.

\section{Site $\mathbf{5 5 9}$}

Hole 559, located between Anomalies 12 and 13 midway between the Oceanographer and Hayes fracture zones (Fig. 3), penetrated $63 \mathrm{~m}$ into basement, encountering uniform aphyric pillow basalts that belong to a single magmatic unit (Fig. 4). Low-temperature alteration effects are variable and randomly distributed, but fresh glass is common at pillow margins. Calcite is present in cracks and veins. The $\mathrm{MgO}$ concentration, about $8 \%$ in fresh samples, decreases to as little as $3 \%$ in badly altered samples. The Site 559 basalts are characterized by a typical enriched distribution of magmaphile elements $\left[(\mathrm{Nb} / \mathrm{Zr})_{\mathrm{ch}}=1.65\right]$. Both magmaphile elements and isotopic data are characteristic of "enriched" MORB (Figs. 5, 6).

\section{Sites 560 and 561}

Hole 560 was drilled on Anomaly 5D midway between the Oceanographer and Hayes fracture zones (Fig. 3 ). At Site 560, serpentinized gabbro and serpentinite with chrysotile veinlets are present throughout the $49 \mathrm{~m}$ of basement cored (Fig. 4). Because the only basalt recovered was a single altered fragment within this serpentinized material, we decided to drill a second hole in the same area. This basalt fragment has a slightly depleted magmaphile element pattern $\left[(\mathrm{Nb} / \mathrm{Zr})_{\mathrm{ch}}=0.8\right]$.
We drilled Site 561 on Anomaly $5 \mathrm{E}$ about 10 miles northwest of Site 560 . We had cored the basement for only $15 \mathrm{~m}$ when the bit failed. Despite this low penetration, we sampled three different chemical groups of aphyric pillow basalts. As at Site 558, these groups include both depleted $\left[(\mathrm{Nb} / \mathrm{Zr})_{\mathrm{ch}}=0.3\right]$ and enriched $[(\mathrm{Nb} /$ $\mathrm{Zr})_{\mathrm{ch}}=2.2$ ] basalts (Fig. 9).

The isotopic signatures of the chemical groups at Site 561 are quite in agreement with the trace-element characteristics (Figs. 5, 6, 7). Hole 561 is a perfect example of local heterogeneities (in terms of mantle sources) and is a strong argument against the notion of long-term steady-state magma chambers.

\section{Site $\mathbf{5 6 2}$}

Hole 562 is located on Magnetic Anomaly 5D, 60 miles south of the Hayes Fracture Zone (Fig. 3). The basement, cored for $90 \mathrm{~m}$, consists of sparsely plagioclase-phyric pillow basalts. Fresh glass is very common at the pillow margins. Despite some altered parts, the bulk of the crystalline basalts are fairly fresh, and we recognized two units on the basis of major-element and trace-element geochemistry (Fig. 4). The magmaphile elements show a typically depleted distribution with a $(\mathrm{Nb} / \mathrm{Zr})_{\mathrm{ch}}$ ratio of 0.3 . Isotopic data are also typical of "normal" depleted MORB (Figs. 5, 6, 7).

\section{Site 563}

Hole 563 was drilled on Anomaly 13, on the same flow line as Hole 562 (Fig. 3). The lower part (156.5-364 $\mathrm{m})$ of the sediment column was continuously cored and showed the same major change in the rate of sedimentation near the lower/middle Miocene boundary as we observed at Site 558, although the carbonate values, averaging $90 \%$, changed only slightly. In addition, a good correlation exists between the sediments studied at Site 563 and the geophysical logs of Site 564 (6 mi. away), the logs and sediments at Site 558, and the logs at Site 556. The change in sedimentation rate near the lower/ middle Miocene boundary can thus be considered a general event in this part of the Atlantic.

The basement was cored for only $18.5 \mathrm{~m}$ because of difficult drilling conditions and a premature bit release. It consists of one petrographic unit of sparsely plagioclase phyric pillow basalts. The on-board magmaphile

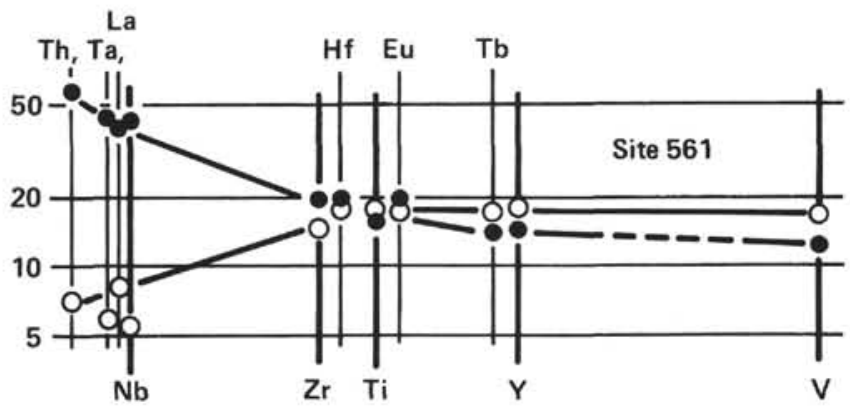

Figure 9. Hole 561: extended Coryell-Masuda plots. On the $x$ axis, the elements indicated at the bottom of the figure $(\mathrm{Nb}, \mathrm{Zr}, \mathrm{Ti}, \mathrm{Y}, \mathrm{V})$ were the objects of on-board measurements, whereas the concentrations of elements indicated at the top were determined on shore. 
element analyses indicate a depleted character $[(\mathrm{Nb} /$ $\left.\mathrm{Zr})_{\mathrm{ch}}=0.3\right]$. Isotopic data are also characteristic of a "depleted" mantle source (Figs. 5, 6).

\section{Site 564}

The poor penetration into the basement at Site 563 (only a single petrographic unit was recovered) forced us to drill another site (6 mi. north) to document better the geochemistry of the basement south of the Hayes Fracture Zone.

At Site 564, we washed down through $284 \mathrm{~m}$ of sediment to the basement, which we then cored for $81 \mathrm{~m}$. The recovered basement section consists of a single petrographic unit of aphyric pillow basalts interrupted by two massive flows (Fig. 4). Fresh glass occurred throughout the sequence. Chemically, the recovered samples form a single group, although forming a compositional gradient. $\mathrm{CaO}$, for example, varies linearly from $12 \%$ at the top to $11.5 \%$ at the bottom with very little scatter. We also noted concentration gradients for the magmaphile elements; it appears that the $\mathrm{Nb} / \mathrm{Zr}$ ratio is not constant downhole. This on-board observation, difficult to verify because of the $\mathrm{Nb}$ analytical precision, has been confirmed by onshore studies (Brannon, this volume). On the basis of the $(\mathrm{Nb} / \mathrm{Zr})_{\text {ch }}$ ratio, which varies from 0.37 to 0.54 , the basalts at this site are depleted. Isotopic data are also typical of “depleted” MORB's (Figs. 5, 6, 7).

We ran a complete set of geophysical logs in Hole 564, deriving the most significant conclusions from the temperature logs. We recorded two temperature profiles to test for thermal equilibrium. The first run was $18 \mathrm{hr}$. after circulation was stopped, and the second was $10 \mathrm{hr}$. later. The two profiles were identical down to below the sediment/basement interface, indicating a low gradient of about $5^{\circ} \mathrm{C} / \mathrm{km}$ (which is only a fraction of the normal gradient). In the basement, between 45 and $60 \mathrm{~m}$, the gradient increased to $250^{\circ} \mathrm{C} / \mathrm{km}$. This provides additional evidence at Anomaly 13 of downflow of seawater when the sedimentary layer is pierced.

\section{Summary}

Drilling operations during Leg 82 were very successful; we were able to achieve both the broad coverage necessary for the major objectives of the cruise and the detailed studies of individual sites required by our secondary objectives. Major results included:

1. There are very few examples of possible cogenetic relationships (i.e., related by shallow-level fractionation) between the basalt units identified at each site.

2. Basalts recovered at Site 556 (Anomaly 13 on the Azores Triple Junction flow line) show depleted magmaphile-element patterns compatible with low ${ }^{87} \mathrm{Sr} /{ }^{86} \mathrm{Sr}$ and high ${ }^{143} \mathrm{Nd} /{ }^{144} \mathrm{Nd}$ ratios. Nevertheless, the high $\mathrm{Pb}$ isotopic ratios require that a particular mantle source was isolated a long time ago, either from an Azores-type plume or from an LVZ-type source.

3. At two sites (558 and 561), we recovered both depleted and enriched material. Together with two previous occurrences at Site 413 (Leg 49) and Hole 504B (Leg 69-70), this finding demonstrates that the association of depleted and enriched magmaphile element patterns at the same site is more common than previously thought. It represents a strong argument in favor of discrete magma chambers.

4. At Site 558, two basalt groups, which have the same "enriched" signature of isotopes, display "enriched" and "depleted" magmaphile element characteristics. This can be explained by recent events that modify the traceelement pattern from "enriched" to "depleted" but do not change the "enriched" signature for isotopic ratios.

5. North of Hayes Fracture Zone, with the exception of the complexities of Hole 556 previously discussed, all sites show the evidence of a contribution of a "plume"type source, even though a typical "depleted" basalt unit is also present at Site 561. South of Hayes Fracture Zone, all sites contain "depleted" MORB.

6. Serpentinites, serpentinized gabbros, and serpentinite breccias occurred at shallow depths at three sites $(556,558$, and 560$)$, suggesting that this material is common in the basement and probably related to normal faulting.

7. We recovered a nearly complete section of lower Oligocene to lower Pleistocene pelagic sediment from this part of the North Atlantic (Site 558 on Anomaly 13). This section will serve as a reference section for biostratigraphy and magnetostratigraphy in the area; of particular importance is the record of a regional increase in the sedimentation rate at about the lower/middle Miocene boundary.

8. Bolboforma-a tiny calcareous algae(?)- - has to date only been recorded from five or six localities. Its discovery in Miocene sediments cored at Site 558 and 563 may provide a good stratigraphic marker and a climatic indicator of cooler temperatures.

9. We can deduce from downhole measurements taken above basement and within the basement that, at Site 556 , seawater began to flow into the hole when the sedimentary layer was pierced. Other groups have observed this process on younger crust (at Sites 335, 395, and 504), and its occurrence on old crust places constraints on its interpretation closer to the ridge.

\section{REFERENCES}

Allègre, C. J., Brevart, O., Dupré, B., and Minster, J. R., 1980. Chemical effect produced in a continuously differentiating correcting earth mantle. Phil. Trans. R. Soc. London, Ser. A, 297:310-341.

Aumento, F., 1968. The Mid-Atlantic Ridge near $45^{\circ} \mathrm{N}$ II. Basalts from the area of Confederation Peak. Can. J. Earth Sci., 5:1-21.

Aumento, F., Melson, W. G., et al., 1977. Init. Repts. DSDP, 37: Washington (U.S. Govt. Printing Office).

Bougault, H., 1977. Major elements: analytical chemistry on board and preliminary results. In Aumento, F., Melson, W., et al., Init. Repts. DSDP, 37: Washington (U.S. Govt. Printing Office), 643-652.

1980. Contribution des éléments de transition à la compréhension de la genèse des basaltes océaniques. Analyse des éléments traces dans les roches par spectrométrie de fluorescence $\mathrm{X}$ [Thesis]. Université Paris VII.

Bougault, H., Cambon, P., Corre, O., Joron, J. L., and Treuil, M., 1979. Evidence for variability of magmatic processes and upper mantle heterogeneity in the axial region of the Mid-Atlantic Ridge near $22^{\circ}$ and $36^{\circ} \mathrm{N}$. Tectonophysics, 55:11-34.

Bougault, H., and Hekinian, R., 1974. Rift valley in the Atlantic Ocean near $36^{\circ} \mathrm{N}$ : petrology and geochemistry of basalt rocks. Earth Planet. Sci. Lett., 24:249-261.

Bougault, H., Joron, J. L., and Treuil, M., 1979. Alteration, fractional crystallization, partial melting, mantle properties from trace elements in basalts recovered in the North Atlantic. In Talwani, M., 
Harrison, C. G., and Hayes, D. E. (Eds.): Deep Drilling Results in the Atlantic Ocean: Ocean Crust: Washington (Am. Geophys. Union), Maurice Ewing Series, 2:352-368.

1980. The primordial chondritic nature and large scale heterogeneities in the mantle: evidence from high and low partition coefficient elements in ocean basalts. Phil. Trans. R. Soc. London, Ser. $A, 297: 203-213$.

Bougault, H., and Treuil, M., 1980. Mid-Atlantic Ridge: zero age geochemical variations between Azores and $22^{\circ} \mathrm{N}$, Nature, 986(5770): 209-212.

Bryan, W. B., and Moore, J. G., 1977. Compositional variations of young basalts in the Mid-Atlantic Ridge rift valley near lat. $36^{\circ} 49^{\prime}$ N. Geol. Soc. Am. Bull., 88:556-570.

Cann, J. R., 1970. Rb, Sr, Y, Zr, and $\mathrm{Nb}$ in some ocean floor basaltic rocks. Earth Planet. Sci. Lett., 10:7-11.

Coryell, C. D., Chase, J. W., and Winchester, J. W., 1963. A procedure for geochemical interpretation of terrestrial rare earth abundance patterns. J. Geophys. Res., 68:559.

DePaolo, D. J., and Wasserburg, G. J., 1976. Inferences about magma sources and mantle structure from variations of ${ }^{143} \mathrm{Nd} /{ }^{144} \mathrm{Nd}$. Geophys. Res. Lett., 3:743-746.

Dmitriev, L., Heirtzler, J. R., et al., 1979. Init. Repts. DSDP, 46: Washington (U.S. Govt. Printing Office).

Donnelly, T., Francheteau, J., Bryan, W., Robinson, P., Flower, M., Salisbury, M., et al., 1980. Init. Repts. DSDP, 51, 52, 53, Pts. 1 , 2: Washington (U.S. Govt. Printing Office).

Dupré, B., and Allègre, C. J., 1980. Pb-Sr-Nd isotopic correlation and the chemistry of the North Atlantic mantle. Nature, 286(5768): 17-22.

Engle, A. E. J., Engle, C., and Havens, R. G., 1965. Chemical characteristics of oceanic basalts and the upper mantle. Geol. Soc. Am. Bull., 76:719-734.

Erlank, A. J., and Kable, E. J. D., 1976. The significance of incompatible elements in Mid-Atlantic Ridge basalts from $45^{\circ} \mathrm{N}$ with particular reference to $\mathrm{Zr} / \mathrm{Nb}$. Contrib, Mineral. Petrol., 54:281.

Frey, F. A., Bryan, W. B., and Thompson, G., 1974. Atlantic ocean floor: geochemistry and petrology of basalts from Legs 2 and 3 of the Deep Sea Drilling Project. J. Geophys. Res., 79: 5507-5527.

Frey, F. A., Haskin. M. A., Poetz, J. A., and Haskin, L. A., 1968. Rare earth abundances in some basic rocks. J. Geophys. Res., 73: 6085-6089.

Gast, P. W., 1960. Limitations on the composition of the upper mantle. J. Geophys. Res., 65:1287-1293.

1968. Trace element fractionation and the origin of tholeiitic and alkaline magma types. Geochim. Cosmochim. Acta, 32: 1057-1086.

Gast, P. W., Tilton, G. R., and Hedge, C. E., 1964. Isotopic composition of lead and strontium from Ascension and Gough Islands. Science, 145:1181-1185.

Hart, S. R., Schilling, J. -G., and Powell, J. L., 1973. Basalts from Iceland and along the Reykjanes Ridge: Sr-isotope geochemistry. Nature, Phys. Sci., 268:707-725.

Hekinian, R., Moore, J. G., and Bryan, W. B., 1976. Volcanic rocks and processes of the Mid-Atlantic Ridge rift valley near $35^{\circ} 49 \mathrm{~N}$. Contrib. Mineral. Petrol., 58:83-110.

Langmuir, C. H., Bender, J. F., Bence, A. E., Hanson, G. N., and Taylor, S. R., 1977. Petrogenesis of basalts from the FAMOUS area: Mid-Atlantic Ridge. Earth Planet. Sci. Lett., 36:133-156.

LeDouaran, S., and Francheteau, S., 1981. Aerial depth anomalies from $10^{\circ}$ to $50^{\circ}$ north along the Mid-Atlantic Ridge: correlation with other mantle properties. Earth Planet. Sci. Lett., 54:29-47.

Luyendyk, B. P., Cann, J. R., et al., 1979. Init. Repts. DSDP, 49: Washington (U.S. Govt. Printing Office).

Masuda, A., 1962. Regularities in variation of relative abundances of lanthanide elements and an attempt to analyze separation-index patterns of some minerals. J. Earth Sci. Nagoya Univ., 10:173-187.

Melson, W. G., Rabinowitz, P. D., et al., 1979. Init. Repts. DSDP, 45: Washington (U.S. Govt. Printing Office).

Menard, H. W., 1967. Sea floor spreading, topography and the second layer. Science, 157:923-924.

Morgan, W. J., 1968. Rises, trenches, great faults and crustal blocks. J. Geophys. Res., 73:1959-1982.

$42-43$
O'Nions, R. K., Evensen, N. M., Hamilton, P. J., and Carter, S. R., 1978. Melting of the mantle past and present: isotope and trace element evidence. Phil. Trans. R. Soc. London, Ser. A, 258: 546-559.

O'Nions, R. K., Hamilton, P. J., and Evensen, N. M., 1977. Variations in ${ }^{143} \mathrm{Nd} /{ }^{144} \mathrm{Nd}$ and ${ }^{87} \mathrm{Sr} /{ }^{86} \mathrm{Sr}$ ratios in oceanic basalts. Earth Planet. Sci. Lett., 34:13-22.

O'Nions, R.K., and Pankhurst, R. J., 1974. Petrogenetic significance of isotope and trace element variations in volcanic rocks from the Mid-Atlantic. J. Petrol., 15:603-634.

O'Nions, R. K., Pankhurst, R. J., and Gronvold, K., 1976. Nature and development of basalt magma sources beneath Iceland and the Reykjanes Ridge. J. Petrol., 17:315-338.

Pearce, J. A., and Cann, J. R., 1971. Ophiolite origin investigated by discriminant analysis using $\mathrm{Ti}, \mathrm{Zr}$, and Y. Earth Planet. Sci. Lett., 12:339-349.

Richard, P., Shimizu, N., and Allègre, C. J., $1977 .{ }^{143} \mathrm{Nd} /{ }^{146} \mathrm{Nd}$ a natural tracer: an application to oceanic basalts. Earth Planet. Sci. Lett., 31:269-278.

Schilling, J. -G., 1973. Iceland mantle plume: geochemical study of Reykjanes Ridge. Nature London, 242:565-575.

1975. Azores mantle blob: rare earth evidence. Earth Planet. Sci. Lett., 25:103-115.

Schilling, J. G., Kingsley, R., and Bergeron, M., 1977. Rare earth abundances in DSDP Sites 332, 334, and 335, and inferences on the Azores Mantle blob activity with time. In Aumento, F., Melson, W. G., et al., Init. Repts. DSDP, 37: Washington (U.S. Govt. Printing Office), 591-598.

Schneitzler, C. C., and Philpotts, J. A., 1970. Partition co-efficients of rare earth elements between igneous matrix material and rock forming mineral phenocryst. Geochim. Cosmochim. Acta, 34: 331-340.

Sclater, J. G., Anderson, R. N., and Bell, W. L., 1971. Elevation of ridges and evolution of the central eastern Pacific. J. Geophys. Res., 76:7888-7915.

Sun, S. S., 1973. Lead isotope studies of young volcanic rocks from oceanic islands, mid-ocean ridges and island arcs [Ph. D. dissert.]. Columbia University, New York.

Sun, S. S., and Jahn, B., 1975. Lead and strontium isotopes in postglacial basalts from Iceland. Nature, 255:527-530.

Sun, S. S., Nesbitt, R. W., and Sharaskin, A. Y., 1979. Geochemical characteristics of mid-ocean ridge basalts. Earth Planet. Sci. Lett., 44(1):119-138

Sun, S. S., Tatsumoto, M., and Schilling, J. -G., 1975. Mantle-plume mixing along the Reykjanes Ridge Axis: lead isotopic evidence. Science, 190:143-147.

Tatsumoto, M., Hedge, C. E., and Engle, A. E. J., 1965. Potassium, rubidium, strontium- 87 to strontium- 86 in oceanic tholeiite basalts. Science, 150:886-888.

Tatsumoto, M., 1978. Isotopic composition of lead in oceanic basalt and its implication to mantle evolution. Earth Planet Sci. Lett., 38:63-88.

Treuil, M., and Joron, J. L., 1975. Utilisation des elements hygromagmatophiles pour la simplification de la modelisation quantitative des processus magmatiques, exemples de l'Afar et de la dorsale medio-atlantique. Soc. Ital. Mineral. Petrol, Milano, XXXI:125174.

Treuil, M., and Varet, J., 1973. Criteres volcanologiques, petrologiques de la genese et de la differenciation des magmas basaltiques: exemple de l'Afar.Bull. Soc. Geol. France, 7th series, XV:506-540.

Vogt, P. R., 1972. Evidence for global synchronism in mantle plume convection, and possible significance for geology. Nature, 240: 338-342.

White, W. M., and Bryan, W. B., 1977. Sr isotope, K, Rb, Cs, Sr, Ba, and rare earth geochemistry of basalts from the FAMOUS area. Geol. Soc. Am. Bull., 88:571-576.

White, W. M., and Schilling, J. -G., 1978. The nature and origin of geochemical variation in Mid-Atlantic Ridge from central N. Atlantic. Geochimica. Cosmochim. Acta, 42:1501-1517.

White, W. M., Schilling, J. -G., and Hart, S. R., 1976. Evidence for the Azores mantle plume from strontium isotope geochemistry of the central N. Atlantic. Nature, 263:659-663.

Wood, D. A., Varet, J., Bougault, H., Corre, O., Joron, J. L., Treuil, M., Bizouard, H., Norry, M. J., Hawkesworth, C. J., and Rod- 
dick, J. G., 1979a. The petrology, geochemistry, and mineralogy of North Atlantic basalts: a discussion based on IPOD Leg 49. In Luyendyk, B. P., Cann, J. R., et al., Init. Repts. DSDP, 49: Washington (U.S. Govt. Printing Office), 597-655.

Wood, D. A., Tarney, J., Varet, J., Saunders, A. A., Bougault, H., Joron, J. L., Treuil, M., and Cann, J., 1979b. Geochemistry of basalts drilled in the North Atlantic by IPOD Leg 49: implications for mantle heterogeneity. Earth Planet. Sci. Lett., 42:77-97.
Zindler, A., and Hart, S. R., 1978. Nd and Sr isotopic compositions and REE abundances in Reykjanes Peninsula basalts: evidence for mantle heterogeneity. EOS, Trans. Am. Geophys. Union, 59:410.

Date of Initial Receipt: 5 December 1983 Date of Acceptance: 13 February 1984 